\title{
Fungal Spore Germination on Natural and Sterile Soil
}

\author{
By D. L. YODER* AND J. L. LOCKWOOD \\ Department of Botany and Plant Pathology, Michigan State University, \\ East Lansing, Michigan, 48823, U.S.A.
}

(Received 29 March I972; revised I I July 1972)

\begin{abstract}
SUMMARY
The germination process of spores of several fungi which require exogenous energy-sources was initiated in non-amended natural soil, a medium deficient in energy-yielding substrates. As measured by subsequent germination time on sterilized soil, this phase accounted for about 8 to $25 \%$ of the total germination time. In conidia of Penicillium frequentans it was irreversible, was inhibited by temperatures of $\mathrm{I}^{\circ} \mathrm{C}$ and was dependent on water alone. Continued progress towards germ-tube formation required exogenous energy-yielding nutrients. When incubation on sterilized soil was interrupted by exposure to non-amended natural soil or a model system designed to imitate the microbial energy-source sink of natural soil, progress towards germination ceased in several fungi. Progress already made towards germination was maintained if the exposure to deprived conditions was short (about 3 days or less), but if longer the germination process reverted towards the water-dependent phase. The reversal, in $P$. frequentans conidia, paralleled the loss of ${ }^{14} \mathrm{C}$ from spores labelled with $\left[{ }^{14} \mathrm{C}\right]$ glucose. When ${ }^{14} \mathrm{C}$-labelled conidia were incubated in an artificial nutrient sink, the label lost was about equally divided between ${ }^{14} \mathrm{CO}_{2}$ and non-gaseous ${ }^{14} \mathrm{C}$-labelled metabolites. Pretreatment of $P$. frequentans conidia in water stimulated uptake of $\left[{ }^{14} \mathrm{C}\right]$ glucose. The results support the view that soil fungistasis in many instances is caused by nutrient deprivation.
\end{abstract}

\section{INTRODUCTION}

Germination of spores of many fungi in soil is restricted to the nutrient-rich environments of plant rhizospheres and plant residues, or follows artificial amendment of soil with energyyielding nutrients. The fungistasis of most soils can be attributed to the lack of essential nutrients in such soils, or the rapid loss of essential endogenous nutrients to competing soil organisms (Ko \& Lockwood, 1967), though some believe that inhibitory substances are involved (Lockwood, 1964).

Steiner \& Lockwood:( 1969$)$ found that spores which required long periods for germination under nutritionally favourable conditions were more sensitive to soil fungistasis than were spores which germinated quickly. The duration of exposure to energy-yielding nutrients was a determining factor in spore germination in soil. Spores exposed to nutrients for periods less than those required for germ-tube formation, then transferred to non-nutritive conditions and later returned to nutritive conditions, required the same total exposure time to nutrients for germination as did spores continuously incubated under favourable conditions.

We have now examined the effect of continuous and intermittent exposure to energysource nutrients and water on germination of spores in soil, whether progress towards germination can be reversed under the competitive conditions of soil, and the fate of accumulated energy substrates when reversal occurs.

\footnotetext{
* Present address: Hunt-Wesson Foods, Inc., Perrysburg, Ohio, 4355I, U.S.A.
} 


\section{METHODS}

Fungal spores. Aspergillus ustus (Bainer) Thom and Church was cultured on V-8 juiceagar (per 1: V-8 juice (Campbell Soup Co.), $200 \mathrm{ml}$; $\mathrm{CaCO}_{3}, 2 \mathrm{~g}$; agar, 20 g). Helminthosporium sativum Pam., King and Bakke was grown on moist, sterilized wheat straws. The following fungi were maintained on potato-dextrose agar: Penicillium frequentans Westling, Fusarium solani (Mart.) Sacc. f.sp. pisi (Jones) Snyd. and Hans., F. oxysporum Schl. f.sp. lycopersici (Sacc.) Snyd. and Hans., F. oxysporum Schl. f.sp. melonis Snyd. and Hans. and Mortierella ramanniana Möller, Linnem. Conidial suspensions were washed 2 to 3 times by refrigerated centrifugation.

Chlamydospores of Fusarium spp. were obtained by a method similar to that of Alexander, Bourret, Gold \& Snyder (1966) using an aqueous extract of Conover loam soil containing sodium polypectate $(0.02 \mathrm{~g} / 100 \mathrm{ml})$. Chlamydospores were detached from mycelia by grinding in a tissue homogenizer (Tri-R Instruments, Jamaica, New York, U.S.A.). They were collected on a 325-mesh sieve and washed 3 times by refrigerated centrifugation.

Spore-germination assays. Conover loam soil (Steiner \& Lockwood, 1969), previously sieved and air-dried, was remoistened to about $57 \%$ of moisture-holding capacity, placed in plastic Petri dishes $(90 \times 15 \mathrm{~mm})$ and the surface smoothed. Plates were incubated about $\mathrm{I} 2 \mathrm{~h}$ before use. Sterilized soil was prepared in glass Petri dishes ( $95 \times 15 \mathrm{~mm})$ and autoclaved at $\mathrm{I} 2 \mathrm{I}{ }^{\circ} \mathrm{C}\left(\mathrm{I} 5 \mathrm{lb} / \mathrm{in}^{2}\right)$ for $30 \mathrm{~min}$. A large $(2 \times 2 \mathrm{~cm})$ Acropor (acrylonitrile polyvinylchloride copolymer) membrane filter (Gelman Instrument Co., Ann Arbor, Michegan, U.S.A., pore size $0.20 \mu \mathrm{m}$ ) was placed directly on the soil surface and two smaller $(\mathrm{I} \times \mathrm{I} \mathrm{cm})$ membranes were located on the larger filter. In some experiments triple-glassdistilled water or an extract of autoclaved subsoil containing glucose $(0.0 \mathrm{I} \mathrm{g} / \mathrm{IOO} \mathrm{ml})$ was added to Petri dishes containing $200 \mu \mathrm{m}$ diam. glass beads to a depth of 5 to $7 \mathrm{~mm}$. The soil extract was prepared by shaking I $\mathrm{kg}$ autoclaved subsoil in I 1 distilled water for $\mathrm{I} h$, then clarifying by centrifugation and sterilizing by membrane filtration. A dilute spore suspension was placed on each small filter.

Germination time on sterilized soil or on glass beads saturated with the soil extractglucose solution was determined by periodically removing membranes bearing spores and staining with phenolic rose bengal. The air-dried membranes were mounted on glass slides in mineral oil for clearing. Germination counts were made of 200 spores on each of two membranes. Spores with germ-tubes equal in length to the diameter of the spore were considered to be germinated. The time required for $50 \%$ germination $\left(\mathrm{GT}_{50}\right)$ was determined by plotting germination percentages as probits against the log of time. When incubation was interrupted by exposure to media deficient in energy-yielding nutrients, the $\mathrm{GT}_{\mathbf{5 0}}$ was expressed as the total time on sterilized soil or nutrient solution resulting in $50 \%$ germination.

Radioisotope studies. Conidia, whose concentration was predetermined, were labelled with ${ }^{14} \mathrm{C}$ by incubating either directly in $\mathrm{x} \mathrm{ml}$ soil-extract-glucose medium in screw-cap test tubes or on membrane filters placed on $200 \mu \mathrm{m}$ diam. glass beads saturated with the same medium. The medium was supplemented with $\left[{ }^{14} \mathrm{C}\right]$ glucose to give a final concentration of $\mathrm{I} \mu \mathrm{Ci} / \mathrm{ml}$ (specific activity, I $\mu \mathrm{Ci} / 5.55 \mathrm{mmol}$ glucose). After incubation directly in the medium, conidia were washed by refrigerated centrifugation and a standard volume was then pipetted on to triplicate filters.

An artificial nutrient sink designed to imitate the microbial nutrient sink of natural soil was constructed to investigate loss of ${ }^{14} \mathrm{C}$ from germinating spores. This was similar in principle to that described previously by Ko \& Lockwood (1967), except that the modified 


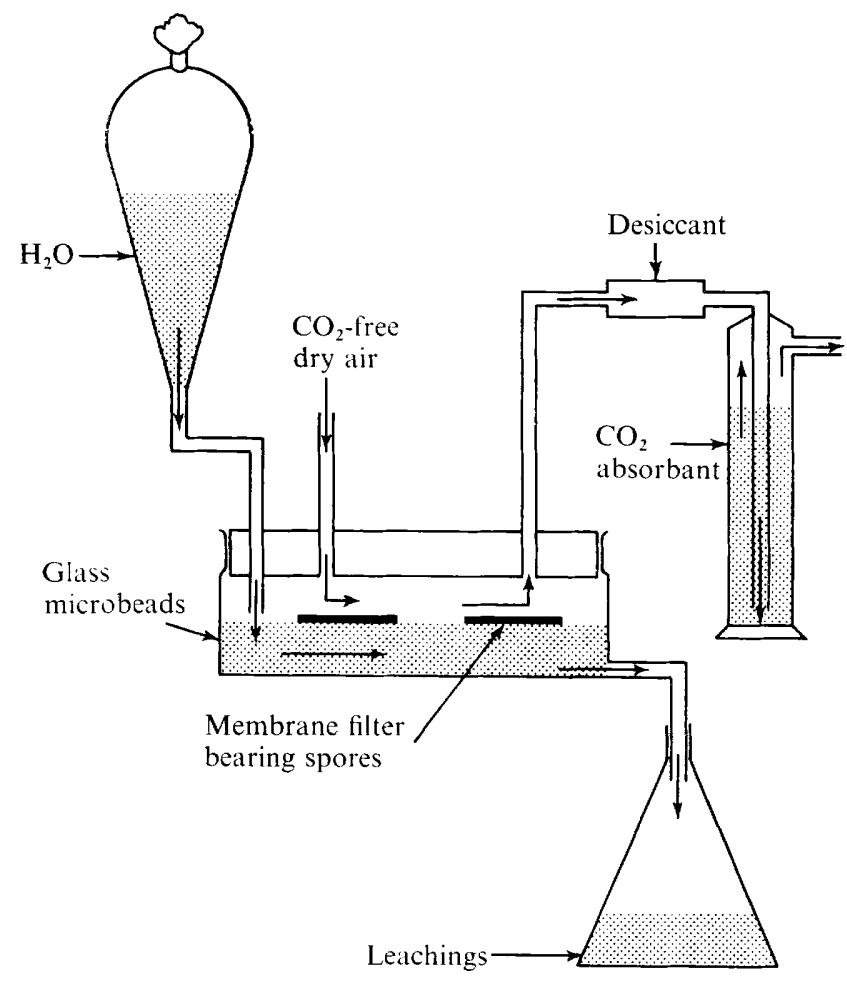

Fig. I. Artificial nutrient-sink designed for collection of $\mathrm{CO}_{2}$ and spore exudates. Dried, $\mathrm{CO}_{2}$-free air entered chamber, constructed from weighing bottle, at left and departed at right, passing through $\mathrm{CO}_{2}$ trap containing methyl cellosolve and ethanolamine $(7: 3, \mathrm{v} / \mathrm{v})$. Water from separating funnel percolated through glass beads $(200 \mu \mathrm{m}$ diam.) supporting the membrane filters and spores in chamber, and was collected in flask at bottom.

model provided for a completely closed chamber for incubating the spores and was so arranged that spore exudates and $\mathrm{CO}_{2}$ evolved could be collected quantitatively (Fig. I).

Radioactivity in the spores was determined in $15 \mathrm{ml}$ modified Bray's scintillation fluid (Bray, I960) (4 g 2,5-diphenyloxazole (PPO) and 0.5 g I,4-di(2-(5-phenyloxazolyl)-benzene) (POPOP) dissolved in $\mathrm{I} 1$ of a mixture $(2: \mathrm{I}, \mathrm{v} / \mathrm{v})$ of toluene and ethylene glycol-monomethyl ether) by means of a Packard Tri-Carb spectrometer.

Aseptic procedures were used unless otherwise indicated. All experiments were run in duplicate and were repeated two or more times.

\section{RESULTS}

Effect of intermittent exposure to sterilized soil on germination time

Conidia of Penicillium frequentans were incubated alternately on sterilized and natural soil for $4 \mathrm{~h}$ periods. After each incubation period some conidia were retained on the same soil plate (up to $24 \mathrm{~h}$ ) to determine germination time. The total time needed for $50 \%$ germination of spores intermittently exposed to sterilized soil was $14 \mathrm{~h}$ as compared with I $5 \mathrm{~h}$ for continuous exposure to sterilized soil $(P>5 \%$; Table I). Thus, the spores appeared to advance stepwise towards germination during the incubation periods on sterilized soil. 
Table I. Effect of alternate incubation periods on sterile and natural soil on germination time of Penicillium frequentans conidia

Incubation condition and time*

\begin{tabular}{|c|c|c|c|c|c|}
\hline $\begin{array}{c}\text { Ist } \\
\text { incubation }\end{array}$ & $\begin{array}{c}2 \text { nd } \\
\text { incubation }\end{array}$ & $\begin{array}{c}3^{\mathrm{rd}} \\
\text { incubation }\end{array}$ & $\begin{array}{c}4^{\text {th }} \\
\text { incubation }\end{array}$ & $\begin{array}{c}5^{\text {th }} \\
\text { incubation }\end{array}$ & $\mathrm{GT}_{50}(\mathrm{~h}) \dagger$ \\
\hline $\mathrm{SS}-$ & - & - & 一 & - & I5 \\
\hline $\mathrm{SS}, 4 \mathrm{~h}$ & NS & - & - & - & No germination \\
\hline $\mathrm{SS}, 4 \mathrm{~h}$ & $\mathrm{NS}, 4 \mathrm{~h}$ & SS & - & - & I 4 \\
\hline $\mathrm{SS}, 4 \mathrm{~h}$ & $\mathrm{NS}, 4 \mathrm{~h}$ & $\mathrm{SS}, 4 \mathrm{~h}$ & NS & - & No germination \\
\hline $\mathrm{SS}, 4 \mathrm{~h}$ & $\mathrm{NS}, 4 \mathrm{~h}$ & $\mathrm{SS}, 4 \mathrm{~h}$ & $\mathrm{NS}, 4 \mathrm{~h}$ & SS & 14 \\
\hline
\end{tabular}

Table 2. Germination times of Penicillium frequentans conidia incubated on sterile soil for 3 or $9 h$, then transferred to natural soil for 3 or 6 days, and subsequently returned to sterile soil

$\begin{array}{cccc}\text { Test } & \begin{array}{c}\text { Time on } \\ \text { sterilized } \\ \text { soil (h) }\end{array} & \begin{array}{c}\text { Time on } \\ \text { natural soil } \\ \text { (days) }\end{array} & \mathrm{GT}_{50}(\mathrm{~h})^{*} \\ \text { I } & \text { Control } \dagger & & 10 \cdot 2 \\ & 3 & 3 & 9 \cdot 1 \\ & 3 & 6 & 8 \cdot 6 \\ 2 & \text { Control } & & 11 \cdot 9 \\ & 9 & 3 & 12 \cdot 2 \\ & 9 & 6 & 16 \cdot 2\end{array}$

* Total time on sterile soil for $50 \%$ germination.

$\uparrow$ Spores incubated continually on sterile soil.

Table 3. Germination times of spores incubated initially on sterile soil, then transferred to natural soil for 6 days, and subsequently returned to sterile soil

\begin{tabular}{|c|c|c|c|c|}
\hline Fungus & Spore & $\begin{array}{c}\text { Time on } \\
\text { sterile } \\
\text { soil (h) }\end{array}$ & $\begin{array}{l}\text { Time on } \\
\text { natural } \\
\text { soil (days) }\end{array}$ & $G T_{50}(h)^{*}$ \\
\hline Aspergillus ustus & Conidia & $\begin{array}{l}\text { Control } \dagger \\
\text { I I }\end{array}$ & 6 & $\begin{array}{l}15 \cdot 3 \\
20 \cdot 5\end{array}$ \\
\hline Fusarium solani f.sp. pisi & Chlamydospores & $\begin{array}{c}\text { Control } \\
3\end{array}$ & 6 & $\begin{array}{l}4 \cdot 6 \\
6 \cdot 8\end{array}$ \\
\hline $\begin{array}{l}\text { Fusarium oxysporum f.sp. } \\
\text { lycopersici }\end{array}$ & Chlamydospores & $\begin{array}{c}\text { Control } \dagger \\
2\end{array}$ & 6 & $\begin{array}{l}3 \cdot 8 \\
6 \cdot 6\end{array}$ \\
\hline $\begin{array}{l}\text { Fusarium oxysporum f.sp. } \\
\text { melonis }\end{array}$ & Chlamydospores & $\begin{array}{c}\text { Control } \dagger \\
2\end{array}$ & 6 & $\begin{array}{l}2 \cdot 5 \\
5 \cdot 7\end{array}$ \\
\hline
\end{tabular}

To determine if the germination progress made during incubation on sterile soil would be maintained during longer incubation on natural soil, conidia of Penicillium frequentans were exposed to sterile soil for 3 or $9 \mathrm{~h}$ and were then transferred to natural soil for 3 or 6 days, after which germination time was determined on sterile soil. Conidia first incubated on sterile soil for $3 \mathrm{~h}$ had $\mathrm{GT}_{50}$ values no greater than those for control spores incubated continually on sterile soil $(P>5 \%)$, whereas conidia first incubated 
Table 4. Effect of pretreatment of spores on natural soil on their germination times

\begin{tabular}{|c|c|c|c|}
\hline Fungus & Spore & $\begin{array}{l}\text { Pre-incubation } \\
\text { time (days) }\end{array}$ & $\mathrm{GT}_{50}(\mathrm{~h})^{*}$ \\
\hline Aspergillus ustus & Conidia & $\begin{array}{c}\text { Control } \dagger \\
6\end{array}$ & $\begin{array}{l}15 \cdot 2 \\
14 \cdot 0\end{array}$ \\
\hline Penicillium frequentans & Conidia & $\begin{array}{c}\text { Control } \dagger \\
6\end{array}$ & $\begin{array}{r}\mathrm{II} \cdot 0 \\
8 \cdot 8\end{array}$ \\
\hline Mortierella ramanniana & Sporangiospores & $\underset{6}{\text { Control } \dagger}$ & $\begin{array}{l}7 \cdot 5 \\
6 \cdot 5\end{array}$ \\
\hline Fusarium solani f.sp. pisi & Chlamydospores & $\underset{6}{\text { Control } \dagger}$ & $\begin{array}{l}4 \cdot 8 \\
4 \cdot 2\end{array}$ \\
\hline Fusarium oxysporum f.sp. lycopersici & Chlamydospores & $\begin{array}{c}\text { Control } \dagger \\
6\end{array}$ & $\begin{array}{l}3 \cdot 8 \\
4 \cdot 6\end{array}$ \\
\hline Fusarium oxysporum f.sp. melonis & Chlamydospores & $\begin{array}{c}\text { Control } \dagger \\
6\end{array}$ & $\begin{array}{l}2 \cdot 7 \\
3 \cdot 2\end{array}$ \\
\hline Helminthosporium sativum & Conidia & Control $\dagger$ & $\begin{array}{l}\mathrm{I} \cdot 6 \\
\mathrm{I} \cdot 0\end{array}$ \\
\hline
\end{tabular}

on sterile soil for $9 \mathrm{~h}$ followed by 6 days on natural soil had $\mathrm{GT}_{50}$ values $4 \mathrm{~h}$ greater than spores incubated continually on sterile soil $(P<5 \%$; Table 2$)$. Thus, a reversal of the germination process occurred when exposure to natural soil was of extended duration.

Conidia of Aspergillus ustus and chlamydospores of Fusarium solani f.sp. pisi, Fusarium oxysporum f.sp. lycopersici and F. oxysporum f.sp. melonis were also incubated on sterilized soil for periods less than required for $50 \%$ germination. The spores were then transferred to natural soil for 6 days, after which germination time was determined on sterilized soil. Substantial reversal was found in all cases $(P<5 \%$ Table 3$)$.

Washed conidia of Aspergillus ustus were incubated on sterilized soil for $10 \mathrm{~h}$ then transferred to natural soil for $0,2,4$ and 6 days. The respective $\mathrm{GT}_{50}$ values of such conidia were I3.0, I6.I, 17.7 and $19.4 \mathrm{~h}$. Similar results were obtained with Penicillium frequentans. Reversal in the germination process was proportional to the time of exposure to natural soil.

\section{Effect of non-amended natural soil on germination progression}

Some of the results (Tables I, 2) suggested that germination times were shortened after incubation on non-amended natural soil. Conidia of Penicillium frequentans and Aspergillus ustus, sporangiospores of Mortierella ramanniana, and chlamydospores of Fusarium solani f.sp. pisi, F. oxysporum f.sp. lycopersici and F. oxysporum f.sp. melonis were incubated on natural soil for 6 days; conidia of Helminthosporium sativum were incubated I day. Germination times were then determined on sterilized soil. With the exception of $F$. oxysporum f.sp. lycopersici and $F$. oxysporum f.sp. melonis, incubation on natural soil resulted in germination progression to the extent of 8 to $15 \%$ as compared with untreated controls $(P<5 \%$; Table 4). By contrast, the two form species of $F$. oxysporum had lengthened germination times.

Washed Penicillium frequentans conidia were incubated on natural soil or on glass beads saturated with triple-glass-distilled water or an extract of autoclaved subsoil for $24 \mathrm{~h}$, and germination times on sterile soil then determined. Subsoil extract was used because topsoil extracts contained anthrone- and ninhydrin-positive materials which stimulated germination. Germination of spores incubated continually on sterile soil required $\mathrm{I} 0 \mathrm{~h}$, whereas 
Table 5. Effect of incubation for $24 h$ at $1{ }^{\circ} \mathrm{C}$ or $24{ }^{\circ} \mathrm{C}$ on natural soil, subsoil extract or water on germination time of Penicillium frequentans conidia subsequently incubated on sterile soil

\begin{tabular}{|c|c|c|}
\hline Treatment & $\begin{array}{c}\text { Temperature } \\
\left({ }^{\circ} \mathrm{C}\right)\end{array}$ & $\mathrm{GT}_{50}(\mathrm{~h})^{*}$ \\
\hline Control, sterile soil & 24 & 10.0 \\
\hline Natural soil & 24 & $7 \cdot 0$ \\
\hline Subsoil extract & 24 & $6 \cdot 5$ \\
\hline Water & 24 & $6 \cdot 3$ \\
\hline Natural soil & I & $8 \cdot 2$ \\
\hline Subsoil extract & I & $8 \cdot 0$ \\
\hline Water & I & $8 \cdot 0$ \\
\hline
\end{tabular}

* Time for $50 \%$ germination on sterile soil.

those pre-incubated on natural soil, subsoil extract and water required 8,7 , and $7 \mathrm{~h}$, respectively. Thus, water alone was as effective as natural soil or subsoil extract in initiating germination $(P>5 \%)$. Time-course experiments indicated that a minimum of $6 \mathrm{~h}$ of incubation on natural soil or water was required to produce a significant progression in the germination process, and that the maximum effect was produced by $15 \mathrm{~h}$ of incubation $(P<5 \%)$.

Conidia of Penicillium frequentans were incubated on natural soil, or on glass beads saturated with either subsoil extract or water at I and $24^{\circ} \mathrm{C}$. After $24 \mathrm{~h}$ of incubation, germination time was determined on sterilized soil. Germination progressed 3 to $3.5 \mathrm{~h}$ at $24{ }^{\circ} \mathrm{C}$, and about $\mathrm{I} \mathrm{h}$ at $\mathrm{I}{ }^{\circ} \mathrm{C}$ as compared with controls incubated directly on sterilized soil (Table 5). Respiratory measurements were made with a Gilson Differential Respirometer at both temperatures: the $Q_{\mathrm{o}_{2}}$ at $24^{\circ} \mathrm{C}$ was $4.28 \times 10^{-8} \mu \mathrm{l} / \mathrm{spore} / \mathrm{h}$ as compared to $7.67 \times$ $\mathrm{I}^{-9} \mu \mathrm{l} / \mathrm{spore} / \mathrm{h}$ at $\mathrm{I}{ }^{\circ} \mathrm{C}$. Thus, respiration was partially inhibited by incubation at $\mathrm{I}{ }^{\circ} \mathrm{C}$. Measurements of I00 Penicillium frequentans conidia were made before and after $24 \mathrm{~h}$ of incubation on water-saturated glass beads at 24 and ${ }^{\circ}{ }^{\circ} \mathrm{C}$. At zero time conidial volumes were $4.64 \pm \mathrm{I} \cdot 24 \mu \mathrm{m}^{3}$. After $24 \mathrm{~h}$ at $\mathrm{I}^{\circ} \mathrm{C}$ volumes were $5 \cdot 06 \pm \mathrm{I} \cdot 32 \mu \mathrm{m}^{3}(P>5 \%)$, whereas at $24{ }^{\circ} \mathrm{C}$ conidia enlarged to $\mathrm{II} \cdot 87 \pm 2 \cdot 27 \mu \mathrm{m}^{3}(P<5 \%)$.

To determine if the water-dependent phase was reversible, conidia of Penicillium frequentans were incubated on natural soil for $24 \mathrm{~h}$, then placed in a desiccator containing Io $\mathrm{g} \mathrm{P}_{2} \mathrm{O}_{5}$ for $24 \mathrm{~h}$. Untreated control conidia germinated on sterilized soil after $8 \cdot 2 \mathrm{~h}$, and control conidia first dried over $\mathrm{P}_{2} \mathrm{O}_{5}$ for $24 \mathrm{~h}$ required $8.8 \mathrm{~h}$. Conidia incubated $24 \mathrm{~h}$ on natural soil, and those incubated on natural soil $24 \mathrm{~h}$ then dried over $\mathrm{P}_{2} \mathrm{O}_{5}$, both germinated on sterilized soil after $7 \cdot 2 \mathrm{~h}(P<5 \%)$. Thus, this phase of germination appeared to be irreversible.

\section{Reversal of the nutrient-dependent phase in an artificial nutrient-sink}

To evaluate nutrient deprivation as the soil factor reversing germination following exposure of spores to energy-yielding nutrients, an artificial nutrient-sink was used. Conidia of Penicillium frequentans were exposed to natural soil or subsoil extract for I day to initiate the water-dependent phase, then were transferred to sterilized soil for $6 \mathrm{~h}$, followed by incubation for 6 days on natural soil or on glass beads leached with subsoil extract, when germination time on sterilized soil was determined. Spores incubated on natural soil lost $75 \%$ [(I I $5-6 \cdot 8) / 6 \mathrm{~h}]$ of the nutrient-dependent phase gained during the $6 \mathrm{~h}$ on sterile soil, whereas spores exposed to the artificial nutrient-sink lost $95 \%$ (Table 6). Thus, the effect of natural soil in reversing the nutrient-dependent phase was approximated quantitatively 


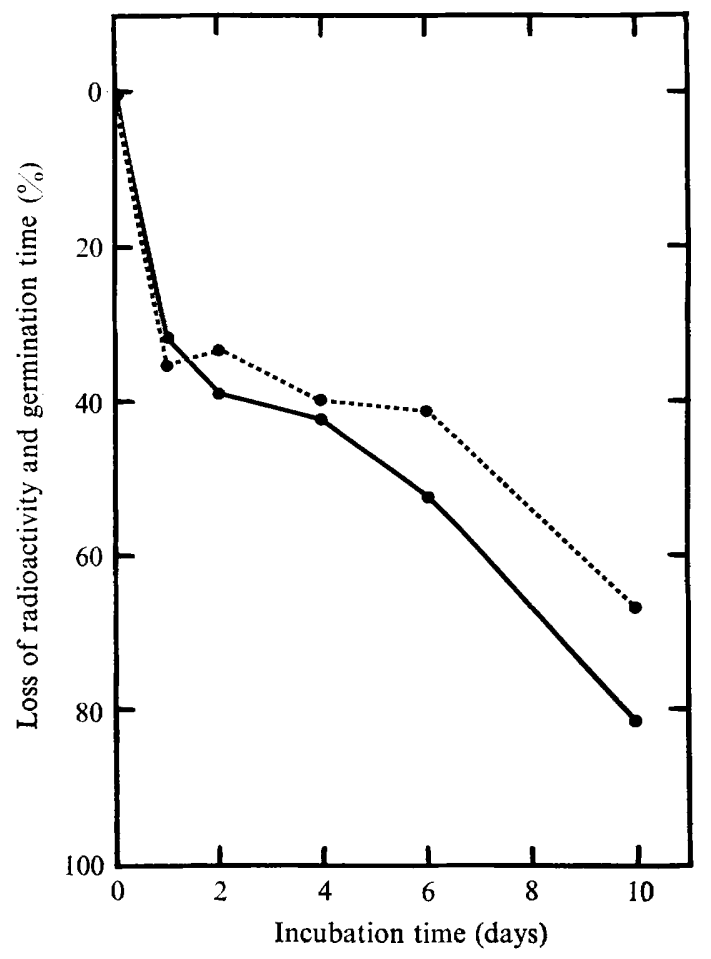

Fig. 2. Relation between reversal in the germination process as measured by germination time and loss of radioactivity during incubation of $\left[{ }^{14} \mathrm{C}\right]$ glucose-labelled conidia of Penicillium frequentans on natural soil. $\longrightarrow$, Radioactivity; $-\cdots$, germination time.

Table 6. Reversal of the nutrient-dependent phase of germination of Penicillium frequentans conidia during incubation on natural soil or in an artificial nutrient-sink*

Incubation condition and time $\dagger$

\begin{tabular}{|c|c|c|c|}
\hline $\begin{array}{c}\text { Ist } \\
\text { incubation }\end{array}$ & $\begin{array}{c}\text { 2nd } \\
\text { incubation }\end{array}$ & $\begin{array}{c}\text { 3rd } \\
\text { incubation }\end{array}$ & $\mathrm{GT}_{50}(\mathrm{~h})$ \\
\hline Control§ & - & - & 9.4 \\
\hline $\begin{array}{l}\text { NS, } 6 \text { days } \\
\text { SSE, } 6 \text { days }\end{array}$ & - & - & $\begin{array}{l}6 \cdot 8 \\
6 \cdot 9\end{array}$ \\
\hline $\begin{array}{l}\text { NS, I day } \\
\text { SSE, I day }\end{array}$ & $\begin{array}{l}\text { SS, } 6 \mathrm{~h} \\
\text { SS, } 6 \mathrm{~h}\end{array}$ & $\begin{array}{l}\text { NS, } 6 \text { days } \\
\text { SSE, } 6 \text { days } \\
\text { (leaching) }\end{array}$ & $\begin{array}{l}\text { II } \cdot 5 \\
\text { I } 2 \cdot 5\end{array}$ \\
\hline
\end{tabular}

* The model system consisted of a Petri dish containing glass beads on which were placed membrane filters bearing the spores. An extract of sterile subsoil from a separating funnel dripped on to the glass beads through an inlet in the dish, and drained through an outlet in the opposite side.

$\dagger \mathrm{NS}=$ natural soil; $\mathrm{SS}=$ sterile soil; $\mathrm{SSE}=$ extract of sterile subsoil.

$\$$ Total time on sterile soil for $50 \%$ germination.

$\S$ Incubated continually on sterile soil. 
Table 7. Fate of ${ }^{14} \mathrm{C}$ in labelled spores of Penicillium frequentans incubated aseptically for 6 days in a model system designed for collection of $\mathrm{CO}_{2}$ and exudates from spores*

\begin{tabular}{lcccc}
\multicolumn{1}{c}{ Source } & Total c.p.m. & c.p.m./spore & Total $(\%)$ & Loss $(\%)$ \\
Initial activity & I I $856 \pm$ I 724 & $0.28 \pm 0.04$ & - & - \\
Spores & $5997 \pm 671$ & $0.14 \pm 0.02$ & 50.6 & - \\
$\mathrm{CO}_{2} \dagger$ & $3239 \pm 352$ & $0.08 \pm 0.01$ & 27.3 & 54.5 \\
Leachings $\$$ & $2620 \pm 235$ & $0.06 \pm 0.0 \mathrm{I}$ & $22 . \mathrm{I}$ & 44.0 \\
$\begin{array}{l}\text { Membrane }+ \\
\text { glass beads }\end{array}$ & $95 \pm 0$ & $0.0 \mathrm{I} \pm 0.00$ & $0 . \mathrm{I}$ & $\mathrm{I} \cdot 6$ \\
Total recovered & I I $952 \pm$ I 258 & $0.28 \pm 0.03$ & IOO.I & I00.0
\end{tabular}

* Conidia were incubated $7.5 \mathrm{~h}$ in a $\left[{ }^{14} \mathrm{C}\right]$ glucose medium, washed and placed on membrane filters in the leaching chamber (Fig. 1).

$+\mathrm{CO}_{2}$ from methyl cellosolve-ethanolamine trap and from boiled leachings similarly trapped.

$\$$ After boiling for $10 \mathrm{~min}$ to remove $\mathrm{CO}_{2}$.

as well as qualitatively by the artificial nutrient-sink. Moreover, by using the same spores for both water-dependent and energy source-dependent phases, the proportion of the latter lost during reversal could be precisely determined.

\section{Loss of energy-yielding substrates from germinating spores on natural soil}

Conidia of Penicillium frequentans were incubated for $7 \mathrm{~h}$ in autoclaved subsoil extract containing glucose $(0.01 \mathrm{~g} / 100 \mathrm{ml})$ and $\left[{ }^{14} \mathrm{C}\right]$ glucose. After labelling, conidia were washed and incubated on natural soil for $0, \mathrm{I}, 2,4,6$ or 10 days. Radioactivity and $\mathrm{GT}_{50}$ were determined after each incubation period.

Percentage reversal and loss of radioactivity, as functions of incubation time on natural soil, were closely parallel $(P<\mathrm{I} \%$; Fig. 2$)$, suggesting that the reversal may have resulted from a loss of glucose, or an energy-yielding metabolite, from spores during incubation on natural soil. To determine the route of loss of acquired energy substrates, the artificial nutrient-sink, modified to collect leachings and $\mathrm{CO}_{2}$ from spores labelled with $\left[{ }^{14} \mathrm{C}\right]$ glucose, was used (Fig. I). Conidia of Penicillium frequentans were incubated in the $\left[{ }^{14} \mathrm{C}\right]$ glucose medium. After $7.5 \mathrm{~h}$, the labelled conidia were washed and pipetted on to membrane filters in the leaching chamber. After incubation for 6 days radioactivity was determined (Table 7 ). About $50 \%$ of the label was lost from the conidia during incubation in the model system. Of this loss about half appeared as ${ }^{14} \mathrm{CO}_{2}$ and half as a non-gaseous product leached from the spores. Other experiments of the same design resulted in a higher proportion of the ${ }^{14} \mathrm{C}$ appearing in the $\mathrm{CO}_{2}$, but total recovery of the label was not complete.

\section{The water-dependent phase as a precursor of the nutrient-dependent phase}

The rates of energy-source uptake by spores pretreated and not pretreated in water were compared. Conidia of Penicillium frequentans were incubated in Petri dishes $(50 \times 15 \mathrm{~mm})$ containing $\mathrm{I} \cdot 5 \mathrm{ml}$ water for $24 \mathrm{~h}$, then these conidia and untreated conidia were incubated in $\mathrm{I} .5 \mathrm{ml}$ subsoil extract containing glucose (0.0 $\mathrm{I} \mathrm{g} / \mathrm{IO0} \mathrm{ml})$ and $\left[{ }^{14} \mathrm{C}\right] \mathrm{glucose}(\mathrm{I} \mu \mathrm{Ci} / \mathrm{ml})$. After incubation for $0, \mathrm{I}, 2,4,6$ and $8 \mathrm{~h}$ the conidia were washed and total ${ }^{14} \mathrm{C}$ activity was determined (Fig. 3). Although excessive variability masked differences which may have occurred early, by $8 \mathrm{~h}$ spores pretreated in water had taken up about four times more $\left[{ }^{14} \mathrm{C}\right]$ glucose than spores not so pretreated. 


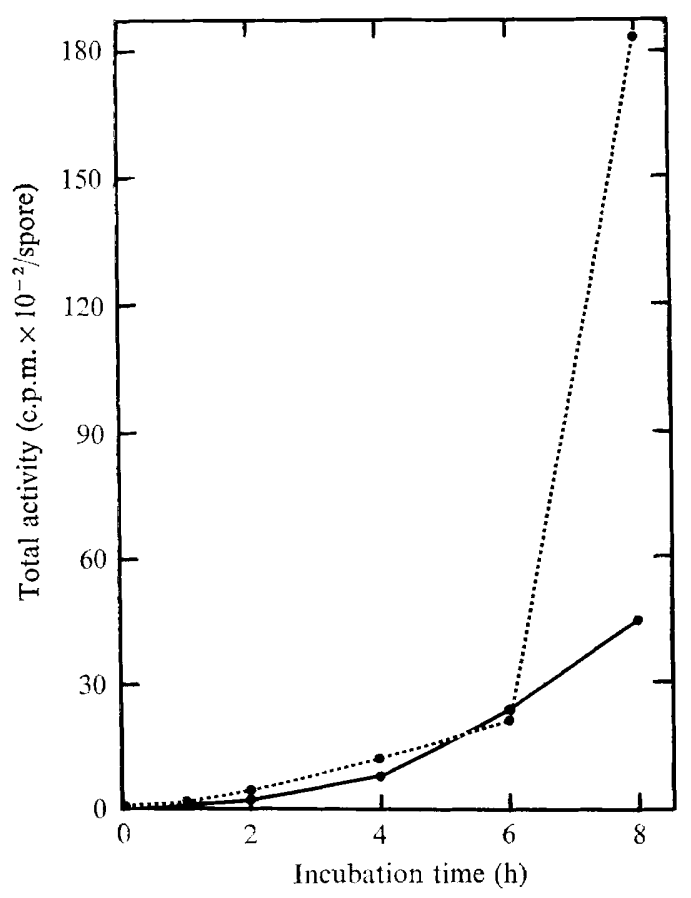

Fig. 3. Effect of $24 \mathrm{~h}$ of pretreatment in water on uptake of $\left[{ }^{14} \mathrm{C}\right] \mathrm{glucose}$ by Penicillium frequentans conidia. - Untreated control; --- , treated.

\section{DISCUSSION}

Spores of all fungal species tested in this study, with the possible exception of chlamydospores of Fusarium oxysporum, made limited progress towards germination during exposure to non-amended natural soil. This phase of germination appeared to require only an aqueous environment, as water alone was as effective as moist natural soil or extract of autoclaved subsoil in promoting it. Possibly, the water-dependent phase involved active metabolism because spore swelling and respiration, and germination progress as measured by germination time, were substantially suppressed by incubating spores at I ${ }^{\circ} \mathrm{C}$. In contrast to our findings, a requirement for exogenous energy sources in spore swelling was implicated in several previous investigations (Cox \& Sisler, I95I ; Yanagita, 1957; Ekundayo \& Carlile, 1964; Marchant \& White, I966; Martín \& Nicolás, 1970). These reports may deal with a later stage in germination than that described in the present work. In our studies, early germination changes were detected by subsequently shortened germination times and were accompanied by minimal spore enlargement.

Sensitivity of spores to soil fungistasis is a function of germination times (Steiner \& Lockwood, 1969). Since 8 to $25 \%$ of the total germination time may occur in soil in the absence of exogenous energy-yielding nutrients, the sensitivity indices previously ascribed to different fungal species were perhaps exaggerated, though their relative order would probably remain unaltered.

Spores incubated under nutritive conditions for short periods maintained their position in the germination process during subsequent short exposures to natural soil. These results confirm those of Steiner \& Lockwood (1969), who used alternate $4 \mathrm{~h}$ incubation periods 
in a nutrient solution and in water. They proposed that fungal spores advanced stepwise and irreversibly towards germination. This interpretation is too restrictive however. When spores were incubated on sterilized soil for longer periods, then transferred to natural soil for long periods, progress towards germination was reversed.

The failure to demonstrate reversal in conidia incubated on natural soil following a short exposure to sterile soil, and the germination progression sometimes observed in such spores, probably resulted from the opposing effects of a barely initiated nutrient-dependent phase and progression in the water-dependent phase. This may also explain the reversal observed with chlamydospores of Fusarium oxysporum during incubation on natural soil (Table 4). Possibly, loss of endogenous reserves (Jones \& Snow, 1965; Daly, Knoche \& Wiese, 1967) may have masked the opposing effect of water in advancing germination.

Loss of ${ }^{14} \mathrm{C}$ from labelled spores during incubation on natural soil provided direct evidence for the loss of previously acquired energy-yielding nutrients, or their metabolites during reversal. Such losses may have caused the reversal. About half of the labelled materials lost from $\left[{ }^{14} \mathrm{C}\right]$ glucose-labelled spores occurred as $\mathrm{CO}_{2}$ and half in exudates. Though materials in the exudate were not identified, amino acids and labelled carboncontaining compounds have previously been reported in exudates from germinating spores of fungi and bacteria (Powell \& Strange, 1953; Jones \& Snow, 1965; Daly et al. 1967). Ko \& Lockwood (1967) reported loss of carbohydrates and amino acids from nutrientindependent conidia of Neurospora tetrasperma leached in a system similar to that used in this research.

The property of natural soil which restricts germination of fungal spores was interpreted by Ko \& Lockwood (1967) to be a general deficiency of energy-yielding nutrients. In the present experiments, incubation in an artificial nutrient-sink imitated natural soil, quantitatively and qualitatively, in reversing the nutrient phase of germination. This provided further evidence that the artificial nutrient-sink is a valid model for the microbial nutrientsink in soil with respect to imposing fungistasis (Ko \& Lockwood, 1967).

The findings of the present research may apply to natural conditions in soil. An aqueous environment appears to initiate limited germination progress, and may prepare the spore for the utilization of exogenous energy sources. If the supply of such nutrients is limited, progress towards germination may cease before germ-tube formation, particularly with small fungal spores which require long periods for germination (Steiner \& Lockwood, I969). Such interrupted spores could progress stepwise towards germination if the intervals between nutrient increments were too short to result in the loss of acquired energy substrates. During longer periods of energy-source deprivation, such spores would revert to their original dormant condition, which would tend to preserve the propagule, since germination in the absence of adequate nutrients would present the sensitive mycelium with conditions known to induce lysis (Ko \& Lockwood, 1970). Fungal spores having larger volumes and requiring a shorter exposure to energy-yielding nutrients for germination (Steiner \& Lockwood, 1969) could more easily colonize and enzymatically utilize more complex organic materials before depletion of water-soluble nutrients. This characteristic may in part account for the success of the Fusarium species, and possibly other species which form chlamydospores and other large resting structures, as soil-borne organisms.

Journal article no. 5815 from Michigan Agricultural Experiment Station. 


\section{REFERENCES}

Alexander, J. V., Bourret, J. A., Gold, A. H. \& Snyder, W. C. (1966). Induction of chlamydospore formation by Fusarium solani in sterile soil extracts. Phytopathology 56, 353-354.

Bray, G. A. (1960). A simple efficient liquid scintillator for counting aqueous solutions in a liquid scintillation counter. Annals of Biochemistry I, 279-285.

Cox, C. E. \& SisLeR, H. D. (195I). Some metabolic and morphologic changes in germinating conidia of Fusarium. Phytopathology 4r (Abstract), 8.

DALY, J. M., KNOCHE, H. W., \& WIESE, M. V. (1967). Carbohydrate and lipid metabolism during germination of uredospores of Puccinia graminis tritici. Plant Physiology 43, 1633-1641.

Ekundayo, J. A. \& CaRlile, M. J., (1964). The germination of sporangiospores of Rhizopus arrhizus: spore swelling and germ tube emergence. Journal of General Microbiology 35, 26I-269.

JoNeS, J. P. \& SNOW, J. P. (I965). Amino acids released during germination of $\mathrm{S}^{35}$-labeled crown rust spores. Phytopathology $\mathbf{5 5}$ (Abstract), 499.

Ko, W. H. \& LockwOoD, J. L. (1967). Soil fungistasis: relation to fungal spore nutrition. Phytopathology 57, 894-901.

Ko, W. H. \& Lockwoon, J. L. (1970). Mechanism of lysis of fungal mycelia in soil. Phytopathology 6o, I48-154.

Lockwood, J. L. (1964). Soil fungistasis. Annual Review of Phytopathology 2, 341-362.

Marchant, R. \& WhITE, M. F. (1966). Spore swelling and germination in Fusarium culmorum. Journal of General Microbiology 42, 237-244.

MARTín, J. B. \& NiCOLÁs, G. (1970). Physiology of spore germination in Penicillium notatum and Trichoderma lignoum. British Mycological Society Transactions 55, I4l-I48.

Powell, J. F. \& Strange, R. E. (1953). Biochemical changes occurring during germination of bacterial spores. Journal of Biochemistry 54, 205-209.

Steiner, G. W. \& Lockwoon, J. L. (1969). Soil fungistasis: sensitivity of spores in relation to germination time and size. Phytopathology 59, 1084-I092.

Yanagita, T. (1957). Biochemical aspects on the germination of conidiospores of Aspergillus niger. Archiv fur Mikrobiologie 26, 329-344. 